\title{
Immediate implant placement: an overview
}

\section{Editorial}

During the 70 years when the osseointegration was introduced, the oral implants were used predominantly on the edentulous patient rehabilitation and the aim was the stomatognathic system function devolution thus contributing positively to restore the patient's psychosocial. During those years the predictable and long term results evidences make extensive this practice to the partial edentulous patients. ${ }^{1}$

It was noticed that the treatment of partial edentulous patient was more complex requiring a harmonic relationship between the implant prosthesis and the remaining natural teeth mainly in anterior regions.

The implant restoration with an acceptable outcome depends on the correct tri dimensional implant placement as well all the tissue architecture that surrounds the implant. In order to succeed in a periimplant aesthetic with single unit implants is a challenge ${ }^{2}$ as well the maintenance.

Despite the high osseointegration success rates, ${ }^{3}$ the focus nowadays is to look what the patient lost in the edentulous site. In order to achieve natural aesthetics a bone improvement or grafting soft tissue is needed and sometimes a combination therapy is necessary to put an implant in an ideal tri-dimensional position and as a result a quality of survival of the implant is conquer.

Since a good foundation is necessary several reports tried to classify the bone defect to make easy the decision for a better treatment option. In 2007, Elian et al. ${ }^{4}$ proposed a classification system for extraction sockets where they evaluated the soft tissue and buccal bone pos-extraction.

Type I Socket: Easiest and predictable. The soft tissue and the buccal bone are at the normal level and remain after the extraction.

Type II Socket: Are often difficult to diagnose and sometimes are treated as a type I by the inexperienced clinician. Facial soft tissue is present but the buccal plate part is missed after the extraction.

Type III Socket: Very difficult to treat and requires bone augmentation and $\mathrm{CT}$ grafts. The soft tissue and the buccal plate are both markedly reduced after tooth extraction. ${ }^{4}$

Funato et al. $^{5}$ described in their article the importance of the timing or the "forth dimension" relative to extraction and implant placement. The timming of tooth extraction and implant placement was classified as follow: Class I: Immediate - extraction, immediate implant placement flapless or with a flap and osseous augmentation with GBR and ct graft.

Class II: Early implant placement (6-8 weeks) - GBR can be performed at the moment of the extraction or when the implant will be placed.

Class III: Delayed Implant placement- 4 to 6 months after the extraction with the preservation of the alveolar ridge with GBR as well soft tissue augmentation. ${ }^{5}$

Jovanovic ${ }^{6,7}$ proposed in his paper a more complete classification and decision maker about the timing:

Kan et al. ${ }^{8}$ described on their paper different scenarios of facial osseous defect. The osseous defect was categorized into V, U or ultra-U
Volume I Issue I - 2014

\author{
Marcia Weiland \\ Marcia Weiland Dental Office, Brazil
}

Correspondence: Marcia Weiland, Marcia Weiland Dental Office, Av of the Americas Room 7707205 block I, Rio de Janeiro-RJ, Brazil, Tel 55-2I-2438-844I,

Emailmarciawl@ig.com.br

Received: April 07, 2014 | Published: April 23, 2014

(UU) shape. A periodontal probe at the midfacial (F), the mesial (MT) and the distal (DT) of the failing tooth and the mesial (MAT) and distal (DAT) aspect of the immediately adjacent teeth. A V shaped osseous defect was considered when it is only affects the F portion of the facial bone plate, an U-shaped osseous defect extended to the MT and DT area and UU-shaped extends into the MAT and DAT area. All the sites received a bone and $\mathrm{CT}$ grafts. The results showed after one year that $8.3 \% \mathrm{~V}$-shaped, $42.8 \%$ U-shaped and $100 \%$ of UU-shaped defects resulted in greater than $1.5 \mathrm{~mm}$ of facial gingival recession. ${ }^{8}$

Both the horizontal and the vertical bone augmentation is well documented in the literature with a predictable results. ${ }^{6,-13}$ During the workshop on Comtemporary Science in Clinical Periodontics, in 2003, a high level of predictability was indicated to the survival of implants in augmented ridge, similar to implants placed in native bone (Annals of Periodontology 2003).

According with Jovanovic, ${ }^{14}$ there are 5 keys that lead us to a quality implant survivor:

1) Bone preservation / regeneration

2) Implant surface / design / position

3) Soft tissue thickness support

4) Prosthetic tissue support

\section{5) Restorative emergence and material}

In the 80 's the implant placement was a functional driven therapy, during the 90's it was understood the importance of the final prosthesis and it was a prosthetic driven therapy. During the 2000 years, more than 20 years of implant therapy, several studies showed us the importance of a biological driven therapy. As these studies demonstrated that there are specific indications to do an immediate implant placement otherwise the outcome will be compromised. To achieve the optimal aesthetic and functional results, the clinicians must analyze what is lost in the implant site and be prepared to rebuild it.

\section{Acknowledgments}

None.

\section{Conflict of interest}

The author declares that there is no conflict of interest. 


\section{References}

1. van Steemberghe D, Lekholm U, Bolender C, et al. Applicability of osseointegrated oral implants in the rehabilitation of partial edentulism: a prospective multicenter study on 558 fixtures. Int J Oral Maxillofac Implants. 1990;5(3):272-281.

2. Kan JYK, Rungcharassaeng K. Site development for anterior implant esthetics: the dentulous site. Compend Contin Educ Dent. 2001;22(3):221-232.

3. Adell R, Lekholm U, Rockler B, et al. A 15-year study of osseointegrated implants in the treatment of the edentulous jaw. Int J Oral Surg. $1981 ; 10(6): 387-416$

4. Elian N, Cho SC, Froum S, et al. A simplified socket classification and repair technique. Pract Proced Aesthet Dent. 2007;19(2):99-104.

5. Funatoa A, Salama MA, Ishikawa T, et al. Timing, positioning, and sequential staging in esthetic implant therapy: a four-dimensional perspective. Int J Periodontics Restorative Dent. 2007;27(4):313-323.

6. Jovanovic SA. Bone rehabilitation to achieve optimal aesthetics. Pract Periodontics Aesthet Dent. 1997;9(1):41-51.

7. Jovanovic SA. Bone rehabilitation to achieve optimal aesthetics. Pract Proced Aesthet Dent. 2007;19(9):569-576.

8. Kan JY, Rungcharassaeng K, Sclar A, et al. Effects of the facial osseous defect morphology on gingival dynamics after immediate tooth replacement and guided bone regeneration: 1-year results. J Oral Maxillofac Surg. 2007;65(7 Suppl 1):13-19.
9. Buser D, Bragger U, Lang NP, et al. Regeneration and enlargement of jaw bone using guided tissue regeneration. Clin Oral Implants Res. 1990;1(1):22-32.

10. Buser D, Dula K, Lang NP, et al. Long-term stability of osseointegrated implants in bone regenerated with the membrane technique. 5-year results of a prospective study with 12 implants. Clin Oral Implants Res. 1996;7(2):175-183.

11. Buser D, Ingimarsson $\mathrm{S}$, Dula $\mathrm{K}$, et al. Long-term stability of osseointegrated implants in augmented bone: a 5-year prospective study in partially edentulous patients. Int $J$ Periodontics Restorative Dent. 2002;22(2):109-117.

12. Jovanovic SA, Spiekermann H, Richter EJ. Bone regeneration around titanium dental implants in dehisced defect sites: a clinical study. Int $J$ Oral Maxillofac Implants. 1992;7(2):233-245.

13. Simion M, Jovanovic SA, Tinti C, et al. Long-term evaluation of osseointegrated implants inserted at the time or after vertical ridge augmentation. A retrospective study on 123 implants with 1-5 year follow-up. Clin Oral Implants Res. 2001;12(1):35-45.

14. Jovanovic SA. Esthetic therapy with standard and scalloped implant designs: the five biologic elements for success. $J$ Calif Dent Assoc. 2005;33(11):873-880. 